\section{TOXICITY OF URIC ACID.}

To the Editors of THE LaNoET.

SIRS,-Dr. Alexander Haig in the last issue of ThE LANCET differs from the opinion that I expressed in my recent address to the Harrogate Medical Society that uric acid possesses no toxic properties whatever. The experiments of Sir A. B. Garrod and others, who administered considerable doses of uric acid or its salts with no very marked toxic effect, are discredited by Dr. Haig on the theoretical assumption that the uric acid was "caught up and retained in the liver, skin, and other tissues," where it was unable to exert its toxic effects. May I ask what proof there is in support of this assumption? I am unable to accept the capillary reflux time or the blood decimal of Dr. Haig as evidence of or against either the presence of uric acid in the blood or its toxicity, while his statements as to the heightened blood pressure due to uric acid are entirely opposed to the most recent investigations on the subject. Dr. I. Walker Hall's experiments, detailed in his book on "The Purin Bodies," show that the blood pressure is not altered by purin bodies, of which uric acid is one.

In support of my belief that uric acid possesses no toxic properties I would adduce the following facts: (1) animals have been made to ingest large quantities of uric acid with their food and urates in solution have been freely injected into their veins without eliciting any signs of poisoning; (2) Filshne in his experiments on frog's muscles found that muscle rigidity and tetanus were produced by hypoxanthin but that uric acid was inert; (3) after carefully searching the literature on the subject the only evidence that I can find of discomfort following the ingestion of uric acid is the statement by Dr. Walker Hall, who, after taking large doses of uric acid, had malaise and headache lasting for several hours. Almost any substance, however (common salt, for example), will produce toxic effects if taken in very excessive quantities. In support of my opinion, as expressed in my Harrogate address, that the deposition of sodium biurate is merely the sign of gout, not the essence of it, and that therefore it should be regarded rather as a symptom than a causative factor, $I$ take the following quotation from Dr. Walker Hall's book on "The Purin Bodies": "Uric acid is a necessary result of normal nuclein metabolism. In disease it is symptomatic of conditions which hinder or prevent its solubility and excretion, and does not itself cause the lesions which accompany uricacidæmia." I am, Sirs, yours faithfully,

Queen Anne-street, W., Dec. 16th, 1905. ARTHUR P. LUFF.

To the Editors of THe LANCET.

SIRs,-In The LaNCET of Dec. 16th Dr. Alexander Haig has shown once more that a purin-free diet systematically persisted in is capable of freeing many patients from a long series of morbid manifestations. He infers that the manifestations dispersed in such cases depend upon the toxic influence of uric acid dissolved in the circulating fluid. Dr. Haig's facts may be admitted. A purin-free diet has now been shown by many to have the capacity claimed, nor can it be questioned that the amount of circulating uric acid is coincidently reduced. But the inference that the former depends upon the latter would not necessarily follow unless it could be shown that the diet which he advocates implies no change other than the reduction of uricæmia. Now there can be no doubt that the enjoinment of a purin-free diet involves at least one incidental change of great importance.

Dr. F. C. Eve, writing in the Practitioner for December, points out that Haig's purin.free diet, vegetarianism, the practice of a prohibitive prolongation of mastication advocated by van Someren, and the dietetic system of Chittenden, all involve a material diminution in the proteid intake, and that all have been found beneficial in the same group of affections. In the "Food Factor in Disease"1 I have given in some detail a long series of cases which go to show that the same group of affections may be successfully treated (often with great rapidity) by a plan of diet which of necessity increases the proteid and purin intake but which materially diminishes the total carbonaceous intake. We are therefore brought to face the following problem: What common effect can be produced on the blood by a diminution of the proteid intake and by a diminution of the carbonaceous intake? The answer is that both tend to diminish

1 Longmans, Green. and Co., 1905. the income to the blood of unoxidised carbonaceons material or fuel, the one by retarding the processes of digestion and absorption, the other by directly reducing the supply of material. It follows that the group of affections referred to-namely, migraine, asthma, gout, high blood pressure, \&c.- depend in many cases upon an excess of fuel, not upon an excess of "ashes" in the blood. And it will be found that many such affections, especially those which are markedly intermittent or periodic, are well adapted to disperse the excess upon which they depend. They may thus be regarded as " pathological functions."

I am, Sirs, yours faithfully,

London, W.C., Dec. 18th, 1905. FraNCIS HaRE.

\section{INSTRUCTION BY POSTER.}

\section{To the Editors of THE LANCET.}

SIRs,-Under the heading of "Medicine and the Law" in THE LANCET of Oct. 26th, a paragraph on Instruction by Poster refers to the course taken by Lambeth of issuing posters giving extracts from the findings of the Inter-departmental Committee on Physical Deterioration, so far as they bear on the evil effects of alcoholism. That paragraph, in addition to questioning the utility of this course, raises a question as to whether such a course is properly within the functions of a sanitary authority. I had expected that some comment would have followed that paragraph in your Cor. respondence columns.

It may readily be conceded that the effect produced by such posters may be less than that desired, but that poster do have a great effect in influencing the public mind is fully proved by the enormous sums which large firms are willing to spend yearly on advertising posters. Unless some such course as this be adopted the weighty findings of that im portant committee will remain within their blue covers and the general populace will have no chance of knowing of them.

The paragraph concedes that a sanitary authority is acting within its proper functions in adopting this method of advertisement against expectoration in the streets. Most active sanitary authorities adopt the advertisement plan, either by posters or circulars, concerning many other things-e.g, infant feeding, infectious diseases, and numerous other matters which may influence health. The paragraph does not make clear to my mind why a sanitary authority should stop short at the evil effects of the abuse of alcohol ; many other authorities besides Lambeth have adopted this course, and to anyone practically acquainted with the poverty and insanitary conditions of great cities it is almost irrefutable that poverty, insanitary surroundings, filth, misery, overcrowding, ill-health, and death are much more intimately associated with the evil effects of alcohol than is any amount of expectoration in the streets. Why, then, should a sanitary authority regard the latter as coming within its purriew and leave the former, as suggested in the paragraph, to benevolent associations or philanthropic individuals?

I am, Sirs, yours faithfully,

Coventry, Dec. 15th, 1905.

E. H. SNelL.

\section{A CASE OF CLAY-COLOURED STOOLS WITHOUT JAUNDICE BUT ATTENDED WITH COPIOUS BILIOUS VOMIT.}

\section{To the Editors of THE LANCET.}

SIRS, - I cannot agree with Mr. A. W. Mayo Robson that a microscope is required to prove that bile enters the alimentary canal in a case characterised by copious vomiting of bile or that exact analysis is needed to show that the norma output of stercobilin in the fæces is reduced when the freshly passed motions, although pale enough to show any fain shade of colour, have not the slightest tinge of brown. But my failure to imagine that stools which contain anything like the normal amount of stercobilin can become "white" simply from solidification of fat on cooling does not aris merely out of this case. Unusually strong proof would be necessary to convince me that in any case a stool such as I describe, pale cream-coloured when passed, contains as much unaltered rich, brown pigment as a normal motion of the same size. Perhaps I am unusually unimaginative. If Mr. Mayo Robson has already published such a proof I must ask him to forgive my having overlooked it. 